\title{
7 EACE THROUGH CULTURAL INTERACTION: THE ETHNIC RELATIONS IN FINLAND AND TURKEY
}

\author{
Adél Furu \\ Babeș-Bolyai University, Cluj-Napoca, E-mail: furuadel@yahoo.com
}

\section{Acknowledgements}

This paper is based on the presentation made at the Fifth international conference on Baltic and Nordic Studies in Romania A piece of culture, a culture of peace, re-imaging European communities in the North Sea, Baltic Sea and Black Sea regions, hosted by Valahia University of Târgovişte and the Romanian Association for Baltic and Nordic Studies, August 17-19, 2014. Supported by EEA Grants, contract no 4/22.07.2014.

\begin{abstract}
:
This paper centres on the ethnic relations in Finland and Turkey, approaching the Black Sea region from a larger geographical and cultural perspective. I will examine how the governments of these two multicultural societies maintain good relations with their linguistic and cultural minorities. Through this paper I point out how close cultural relations with the Sami people maintain the peace in Finland. Peace in this area is implemented through culture and education. I will describe how Finland is involved in the implementation of educational programmes for the Sami and how it aims at acquainting the Finnish majority with various aspects of Sami cultural traditions. Moreover, the dialogue between these two cultures plays an important role in eliminating the prejudice that has stirred up conflicts for so many decades. Since the problem of the Kurdish people in Turkey is not only a problem within the borders, but also an international problem, in this paper I look at the ways in which the aspirations of the Kurds in Turkey have an impact on cross-border minority aspirations as well. Therefore, Turkey is expected to embrace a liberal legal approach and should put emphasis on the liberalization of minority politics.
\end{abstract}

\section{Rezumat:}

$\hat{I n}$ această lucrare ne îndreptăm atenția asupra relațiilor etnice din Finlanda şi Turcia. Voi examina modul în care guvernele acestor două societăți multiculturale mențin relații bune cu minoritățile lor lingvistice şi culturale. Relațiile culturale strânse cu populația Sami mențin pacea în Finlanda. Pacea în această zonă este implementată prin cultură şi educație. Voi descrie modul $\hat{\imath}$ care Finlanda este implicată $\hat{\imath}$ punerea $\hat{\imath}$ aplicare a programelor educaționale pentru Sami şi modul în care aceasta are drept scop familiarizarea majoritătii finlandeze cu diverse aspecte ale traditiilor culturale Sami. Mai mult decât atât, dialogul dintre cele două culturi joacă un rol important în eliminarea prejudecăților, care au stârnit conflicte de zeci de ani. Având în vedere că problema poporului kurd din Turcia nu este doar o problemă în interiorul granițelor, dar şi o problemă internațională, voi evidenția modul în care 
70 | Revista Română de Studii Baltice și Nordice / The Romanian Journal for Baltic and Nordic Studies 6 (2) aspirațiile kurzilor din Turcia au un impact asupra aspirațiilor minorităților transfrontaliere. Prin urmare, Turcia trebuie să adopte o abordare juridică liberală şi ar trebui să pună accent pe liberalizarea politicii minoritare.

Keywords: Ankara, Kurds, Finland, Sami, international law, cross-border minority aspirations

The understanding and analysis of the relationship between language-ethnicityculture-identity assume the language - one's mother tongue and other languages. Without analysis and understanding the strategy planning and action may be ineffective, or may lead to assimilation. The denial of relationships and belittling the role of human rights (in particular the linguistic human rights) is destructive, and it is often used as an argument by politicians.

\section{Finland. Policy on national minorities - the Samis and their linguistic rights}

The Sami are the only ethnic group in the European Union, which is recognized as an indigenous people. The Sami language has an outstanding status among the minority languages in Finland. The Finnish law contains special provisions for the Sami language. These are summarized in the current Finnish Constitution:

According to section 17, paragraph (3) of the current Finnish Constitution (2000, amended 2004): The Sami, as an indigenous people, as well as the Roma and other groups, have the right to maintain and develop their own language and culture. Provisions on the right of the Sami to use the Sami language before the authorities are laid down by an Act [...].

Paragraph (4) of section 121 states that: Provisions on self-government in administrative areas larger than a municipality are laid down by an Act. In their native region, the Sami have linguistic and cultural self-government, as provided by an Act. ${ }^{1}$

\section{International documents that provide support for the Sami}

1) According to paragraph (2) of art. 2 of the UN Declaration on the Rights of Persons Belonging to National or Ethnic, Religious and Linguistic Minorities (1992): Persons belonging to minorities have the right to participate effectively in cultural, religious, social, economic and public life. ${ }^{2}$

2) Article 27 of the International Covenant on Civil and Political Rights (1966) was adopted by all 3 Scandinavian countries. Art. 27 states that: In those States in which ethnic, religious or linguistic minorities exist, persons belonging to such minorities shall not be denied the right, in community with the other members of their group, to enjoy their own culture, to profess and practise their own religion, or to use their own language. ${ }^{3}$

\footnotetext{
${ }^{1}$ http:/ / www.servat.unibe.ch/icl/fi00000_html, accessed at 26.09.2014

2 http://www.un.org/documents/ga/res/47/a47r135.htm, accessed at 23.09.2014

3 http://www.ohchr.org/en/professionalinterest/pages/ccpr.aspx, accessed at 26.09.2014
} 
3) The next document which deals with the situation of the Sami too, refers to the customs, traditions and institutions of indigenous peoples. According to paragraph (2b) of art. 2 of the Indigenous and Tribal Peoples Convention (1989) (No. 169): Such action shall include measures for: [...] (b) promoting the full realisation of the social, economic and cultural rights of these peoples with respect for their social and cultural identity, their customs and traditions and their institutions; [...].4

4) In addition, in 1997 Finland ratified the Framework Convention for the Protection of National Minorities. The objective of the Convention is the effective protection of national minorities and respect for ethnic, cultural and linguistic identity of persons belonging to national minorities.

Paragraph (1) of art. 5 of the Convention states that: The Parties undertake to promote the conditions necessary for persons belonging to national minorities to maintain and develop their culture, and to preserve the essential elements of their identity, namely their religion, language, traditions and cultural heritage. ${ }^{5}$

\section{Institutions representing the Sami people}

\section{a. the Sami Parliament 6 .}

Paragraph (1) of section 1 of the current Act on the Sami Parliament (974/1995; amendments up to 1026/2003 included, laki saamelaiskäräjistä) states that: The Sámi, as an indigenous people, have linguistic and cultural autonomy in the Sámi homeland as provided in this Act and in other legislation. For the tasks relating to cultural autonomy the Sámi shall elect from among themselves a Sámi Parliament.

Paragraph (1) of section 5 states that: The task of the Sámi Parliament is to look after the Sámi language and culture, as well as to take care of matters relating to their status as an indigenous people.

Paragraph (1) of section 9 of the same Act states that: The authorities shall negotiate with the Sámi Parliament in all far-reaching and important measures which may directly and in a specific way affect the status of the Sámi as an indigenous people and which concern the following matters in the Sámi homeland: [...]

(4) legislative or administrative changes to the occupations belonging to the Sami form of culture;

(5) the development of the teaching of and in the Sami language in schools, as well as the social and heal th services; or

(6) any other matters affecting the Sami language and culture or the status of the Sami as an indigenous people. ${ }^{7}$

\footnotetext{
${ }^{4}$ http://www.ilo.org/wcmsp5/groups/public/---ed_norm/--normes/documents/publication/wcms_100897.pdf, accessed at 26.09.2014

${ }^{5} \mathrm{http}: / /$ conventions.coe.int/Treaty/en/Treaties/Html/157.htm, accessed at 23.09.2014

6 Established in Finland in 1973, in Norway in 1989 and in Sweden in 1993, while in Russia a Sami parliament does not even exist today.

${ }^{7}$ http://www.finlex.fi/fi/laki/kaannokset/1995/en19950974.pdf, accessed at 26.09.2014
} 
b. the Sami Council - protecting the rights of the Sami in Finland, ensures the survival of the Sami language and culture and decides on the allocation of financial resources;

c. The Advisory Board on Sami Affairs - cooperates with the Ministry of Justice in order to prepare and coordinate the affairs of the Sami people. Furthermore, the Advisory Board monitors the evolution of the cultural, social and economic life of the Sami people. The Advisory Board submits proposals to the relevant ministries.

\section{Middle Eastern minority language policy}

The biggest problem of the modern Arabian political life is the status of minorities - whether they are national, ethnic or religious minorities - in the state administration and in society. In many Arabian states the mere mention of the topic has been a taboo for a long time, as it collided with the vision of the national state. Recently, however, the penetration into the Arab political discourse of such terms as democracy, pluralism and civil society changed the situation. The penetration of these concepts has an impact on the state-minority relations, and challenges the authoritarian Arab regimes.

The Kurdish problem in Turkey is not only a problem within the borders, but also an international problem. Since the Kurds live in more than one country, the aspirations of the people of a country have an impact on cross-border minority aspirations as well. Therefore, Turkey is expected to embrace a liberal legal approach, and should place emphasis on the liberalization of minority politics. If it refuses to pursue a policy that is in line with the political and cultural aspirations of the minorities, it violates the most basic human rights, and crushes the democratic institutions. Thus the state will not be attractive as a new member of the EU.

The Kurdish issue has reached Western Europe as well, as Turkey propagated its linguicist ideology by the European embassies: it put diplomatic pressure on the European countries so that they do not teach the Kurdish language to the Kurdish immigrants and their children in school ${ }^{9}$. However, this policy violates numerous provisions of international conventions such as:

- The Charter of the United Nations (ratified by Turkey on 28th September 1945);

- the Universal Declaration of Human Rights (1948), which summarizes the UN's position of every person's fundamental rights, and that is based on the

\footnotetext{
8 Gabriel Ben-Dor, "Minorities in the Middle East: Theory and Practice", in Minorities and the State in the Arab World, ed. O. Bengio, G. Ben-Dor (Boulder, Colorado: Lynne Rienner Publishers, 1999), $3-$ 22.

9 Amir Hassanpour, "The Politics of A-political Linguistics: Linguists and Linguicide", in Rights to Language. Equity, Power, and Education, ed. R. Phillipson (Mahwah, New Jersey, London: Lawrence Erlbaum Associates, 2000), 33-39.
} 
principle of equality, human rights and freedoms and the prohibition of discrimination (Turkey signed it on 10th December 1948);

- International Covenant on Civil and Political Rights (1966) (ratified by Turkey on 23rd September 2003);

- International Covenant on Economic, Social and Cultural Rights (1966) (ratified by Turkey on 23rd September 2003);

- Convention on the Rights of the Child (UN, 1989) (Turkey ratified it on 4th April 1995). Article 30 states that: In those States in which ethnic, religious or linguistic minorities or persons of indigenous origin exist, a child belonging to such a minority or who is indigenous shall not be denied the right, in community with other members of his or her group, to enjoy his or her own culture, to profess and practise his or her own religion, or to use his or her own language. ${ }^{10}$

The convention draws attention to the fact that the rights of children require special protection, since every community passes the cultural heritage on to their children and it survives through them.

When signing the Convention, Turkey expressed reservations in relation to Article 30. However, Article 13 of the draft Declaration on the Rights and Obligations of States (1949) states that every country has the obligation to fulfill the obligations arising from international law, and cannot rely on provisions of the Constitution when it does not fulfill its duty.

However, Thornberry (2002) ${ }^{11}$ stresses that from the point of view of international treaties and conventions it is not determining whether the internal law of a state recognizes or even denies the basic human rights of minorities.

- The European Charter for Regional or Minority Languages (1992), which was not ratified by Turkey, thus the regulations for the recognition of minority languages do not apply.

Half a million Kurds live in Germany and their political activities affect the activities of the Kurds in Turkey, and have an impact on the EU and NATO, as they are forced to take a position on the Kurdish problem in Turkey. A number of politically motivated Kurds escaped to the West, and there continued their national struggle. Thus, the Kurdish question in Turkey took on an international dimension. Political activities of the Kurdish diaspora in Europe made European governments intervene and exert pressure on Ankara. The EU will exert pressure on Turkey's democratic institutions to facilitate the transition from a constitutionally recognized homogeneous society to the formally announced multiethnic society. Due to the

\footnotetext{
10 http://www.ohchr.org/en/professionalinterest/pages/crc.aspx, accessed at 23.09.2014

11 Patrick Thornberry, “Az ENSZ Nemzeti vagy etnikai, vallási és nyelvi kisebbségekhez tartozó személyek jogairól szóló Nyilatkozata: háttér, elemzés, megjegyzések és a legújabb fejlemények”, in Kisebbségi Adattár XI., Kisebbségvédelem és a nemzetközi szervezetek, ed. N. Bárdi (Budapest: Teleki László Alapítvány, 2002), 9-74.
} 
Kurdish question a change occurred in the Turkish foreign policy: Turkey's relations with the United States, Europe, the Middle East and Russia deteriorated, and Turkey succeeded in stirring up international public opinion.

Turkey's energy and resources should be directed to the peaceful economic, social and cultural development of the country, and it has the duty to discourage hatred and prejudice against minorities, and should adopt the principles of peaceful coexistence and friendly co-operation. Peace among different linguistic groups is of greatest value which must be embraced by all political, social and religious movements. Turkey should be guided by the goal of creating conditions of the common existence and co-operation in peace, equality and mutual understanding of the Turkish and Kurdish nations. The essential role of the Turkish government, as well as different national and international organizations, the mass media, the Turkish educational system and teaching methods is to promote the ideals of peace, unity and understanding among minorities.

Turkey should create unity and good relations between the different ethnic groups based on the following important values which should be charished: education for a culture of peace, free flow of information and knowledge, respect for all human rights ${ }^{12}$. Turkey should also focus on the principal of justice and equality for all its linguistic minorities. Respecting the culture of peace based on the principles of independence, human rights, sustaining development, freedom of expression, justice, tolerance and solidarity, wisdom, experience, democracy, cooperation, exchange, interchange, cultural diversity will ease the communication and understanding at the entire level of society and among the existing minorities.

Close cultural relations lead to peace. The dialogue among different cultures should play an important role in eliminating prejudice. The main task of Turkey is the defence of peace which should be implemented through culture. Since education is crucial, Turkey should be actively involved in the implementation of the "education for all".

\section{Conclusions}

Turkey and Finland are multicultural states which consist of various different ethnic groups. So it is important both for the governments and for the societies to cooperate with each other in order to maintain good relations with all the ethnic groups. It is important for linguistic minorities to further improve all aspects of their lives: long-term political constancy, economic, cultural and social well-being and enhanced educational services. Cultural elements like ethnicity, region, history, language and religion also play an important role so they must be preserved in

12 Vizi Balázs, “A mai európai nemzetközi kisebbségvédelem egyes jellemző vonásai”, in Tér és terep. Tanulmányok az etnicitás és az identitás kérdésköréböl, ed. Szarka L., Kovács N. (Budapest: Akadémiai Kiadó, 2002), 367-389. 
order to have a respectable relationship between the different linguistic groups and to live in a harmonious country. Respecting each other's culture, customs and religion helps all ethnic groups get closer. Both states should be aware that great unity among all ethnic groups can narrow the gap between different communities and can prevent future ethnic conflicts. Moreover, good ethnic relations are very important in Turkey in order to ensure that there would not be any feelings of ethnic pride which can lead to prejudice and intolerance and in order to preserve the integrity of the country and of the nation itself in the future.

\section{References:}

\section{A. Books and articles:}

Ben-Dor, Gabriel. 'Minorities in the Middle East: Theory and Practice.' In Minorities and the State in the Arab World. Ed. Ofra Bengio, Gabriel Ben-Dor. Boulder, Colorado: Lynne Rienner Publishers, 1999, 3-22.

Hassanpour, Amir. 'The Politics of A-political Linguistics: Linguists and Linguicide.' In Rights to Language. Equity, Power, and Education. Ed. Robert Phillipson. Mahwah, New Jersey, London: Lawrence Erlbaum Associates, 2000, 33-39.

Thornberry, Patrick. 'Az ENSZ Nemzeti vagy etnikai, vallási és nyelvi kisebbségekhez tartozó személyek jogairól szóló Nyilatkozata: háttér, elemzés, megjegyzések és a legújabb fejlemények'. In Kisebbségi Adattár XI., Kisebbségvédelem és a nemzetközi szervezetek. Ed. Bárdi Nándor. Budapest: Teleki László Alapítvány, 2002, 9-74.

Vizi, Balázs. 'A mai európai nemzetközi kisebbségvédelem egyes jellemző vonásai.' In Tér és terep. Tanulmányok az etnicitás és az identitás kérdésköréból. Ed. Szarka László, Kovács Nóra. Budapest: Akadémiai Kiadó, 2002, 367-89.

\section{B. Web postings:}

http:// www.servat.unibe.ch/icl/fi00000_html, accessed at 26.09.2014

http://www.un.org/documents/ga/res/47/a47r135.htm, accessed at 23.09.2014

http://www.ohchr.org/en/professionalinterest/pages/ccpr.aspx, accessed at 26.09.2014

http://www.ilo.org/wcmsp5/groups/public/---ed_norm/--normes/documents/publication/wcms_100897.pdf, accessed at 26.09.2014

http://conventions.coe.int/Treaty/en/Treaties/Html/157.htm, accessed at 23.09.2014 http://www.finlex.fi/fi/laki/kaannokset/1995/en19950974.pdf, accessed at 26.09.2014

http://www.ohchr.org/en/professionalinterest/pages/crc.aspx, accessed at 23.09.2014 